\title{
Water, nitrogen and ploidy effects on Russian wildrye min- eral concentrations
}

\author{
J.F. KARN, A.B. FRANK, J.D. BERDAHL, AND W.W. POLAND
}

Authors are Research Animal Scientist, Plant Physiologist, and Plant Geneticist, USDA, Agricultural Research Service, Northern Great Plains Research Laboratory, P. O. Box 459, Mandan, N.D. 58554, and ruminant nutritionist, North Dakota State University, Dickinson Research Extension Center, Dickinson, N.D. 58601 .

\section{Abstract}

High quality forage for spring and autumn grazing can be obtained from Russian wildrye [Psathyrostachys juncea (Fisch.) Nevski], a cool-season bunchgrass. However, little is known about mineral concentrations critical to livestock production, especially in the relatively new tetraploid plants. A knowledge of plant mineral concentrations and how they can be manipulated to more nearly meet animal requirements is necessary to optimize animal production. A study was undertaken to determine the extent that concentrations of critical minerals in leaf and stem tissue of Russian wildrye were affected by ploidy level, growing-season water (50 and $150 \%$ of average), and $\mathrm{N}$ fertilizer (10 and $134 \mathrm{~kg} \mathrm{~N} \mathrm{ha}^{-1}$ ). Plants were sampled at vegetative, boot, anthesis, and anthesis plus 10-day stages of maturity in 1994, 1995, and 1996. Ploidy level resulted in small but significant differences in some mineral concentrations, with diploid plants usually having higher levels. An exception was $P$ in stem tissue. This finding indicates that in breeding and selection for other traits, forage quality was not adversely affected. Growing-season water level also had minimal effects on mineral concentrations, except for $P$ which was enhanced $(P<0.05)$ by greater amounts of soil water. Fertilizer $\mathrm{N}$ increased forage levels of $\mathrm{Ca}, \mathrm{K}, \mathrm{Cu}$, and $\mathrm{Zn}$, and decreased levels of $P$. Higher concentrations of $K$ are not desirable, because they increase the possibility of a grass tetany problem. Advancing plant maturity caused a decrease in $P$ and $\mathrm{Zn}$ concentrations, but $\mathrm{Ca}$ and $\mathrm{Mg}$ in leaf tissue increased as plants matured. These results suggest that concentrations of $P$, $\mathrm{Ca}, \mathrm{Mg}$, and $\mathrm{Cu}$ were marginal for high producing cattle at some stages of maturity, but we found the effects of nitrogen and growing-season water did not result in leaf and stem mineral concentration changes that would adversely affect the safety and nutritive quality of Russian wildrye.

Key Words: diploid, tetraploid, stage of maturity, rain shelter

Mineral analyses for this research was funded by a grant from the North Dakota Board of Agricultural Research.

Mention of a trade name is solely to identify materials used and does not constitute endorsement by the U. S. Department of Agriculture. The authors wish to thank Dr. Gary V. Richardson and Dr. Mark West for advice with statistical procedures.

U. S. Department of Agriculture, Agriculture Research Service, Northern Plains Area, is an equal opportunity/affirmative action employer and all agency services are available without discrimination

Manuscript accepted 26 Nov. 02.

\section{Resumen}

Forraje de alta calidad para el apacentamiento en primavera y otoño puede ser obtenido del "Russian wildrye" [Psathyrostachys juncea (Fisch.) Nevski], un zacate amacollado de crecimiento invernal. Sin embargo, poco se conoce acerca de las concentraciones minerales criticas para la producción del ganado, especialmente en las plantas tetraploides, las cuales son relativamente nuevas. Es necesario un conocimiento de las concentraciones de minerales en las plantas y como ellas pueden ser manipuladas para casi satisfacer los requerimientos del animal necesarios para optimizar su producción. Se condujo un estudio para determinar en que cantidad el nivel de poliploidia, el agua en la estación de crecimiento ( 50 y $150 \%$ del promedio) y la fertilización $N$ (10 and $134 \mathrm{~kg} \mathrm{~N} \mathrm{ha}^{-1}$ ) afectaron las concentraciones de minerales críticos en el tejido de hoja y tallo del "Russian wildrye", Las plantas fueron muestreadas en 1994, 1995 y 1996 en los estados de madurez de: crecimiento vegetativo, embuche, antesis, y 10 días después de antesis. El nivel de poliploidia resulto diferencias pequeñas, pero significativas, de la concentración de minerales, las plantas diploides usualmente tuvieron los mayores niveles. Una excepción fue el $P$ en el tejido del tallo. Estos hallazgos indican que en el mejoramiento y selección de otras características la calidad del forraje no fue afectada adversamente. El nivel de agua en la estación de crecimiento también tuvo efectos mínimos en las concentraciones de minerales, excepto el $P$ el cual fue incrementado $(P<0.05)$ por las grandes cantidades de agua del suelo. La fertilización $\mathbf{N}$ incremento los niveles de $\mathrm{Ca}, \mathrm{K}, \mathrm{Cu}$ y $\mathrm{Z}$ y disminuyo los niveles de $\mathrm{P}$. Altas concentraciones de $K$ no son deseables porque ellas incrementan la posibilidad de tener problemas de tetania de los pastos. El avance de la madurez de las plantas causo una disminución en la concentración de $\mathrm{P}$ y $\mathrm{Zn}$, pero el Ca y el $\mathrm{Mg}$ del tejido de la hoja incremento conforme la planta maduro. Estos resultados sugieren que en algunas etapas de madurez las concentraciones de $\mathbf{P}, \mathrm{Ca}, \mathrm{Mg}$ y $\mathrm{Cu}$ fueron marginales para ganado de alta productividad, pero encontramos que la fertilización $\mathbf{N}$ y el nivel de agua en al estación de carecimiento no resultaron en cambios de la concentración de minerales del tejido el hojas y tallos que pudieran afectar adversamente la seguridad y calidad nutritiva del "Russian wildrye".

Russian wildrye, a cool-season bunchgrass, was introduced into the United States from the U.S.S.R. in 1927 (Johnson and Nichols 1970). It has potential as a valuable forage for spring and autumn grazing in the Northern Great Plains, but little is known about the concentration of minerals critical to livestock production (NRC 1996), potential mineral concentration differences 
among cultivars, or the effect of environmental conditions on plant mineral levels. Some scientists (Asay and Mayland 1990, Jefferson et al. 2001) have indicated that Russian wildrye may cause grass tetany in spring, when its nutritive quality is high (Karn et al. 1983). Grass tetany (hypomagnesemia), is an often fatal metabolic disorder primarily affecting lactating cows. It is thought to be caused by low forage $\mathrm{Mg}$ and $\mathrm{Ca}$ levels, and is exacerbated by high levels of $\mathrm{K}$ and crude protein (Committee on Mineral Nutrition 1973). Research with tall fescue [(Festuca arundinacea Schreb.), Reeder et al. 1986, Sleper et al. 1989], annual ryegrass [Lolium L. (Poaceae), Hides and Thomas 1981] and Russian wildrye (Jefferson et al. 2001) suggests that the incidence of grass tetany could be reduced by modifying forage mineral concentrations, especially $\mathrm{Mg}$, through plant breeding and selection. Little is known, however, about levels of other minerals in Russian wildrye, such as $\mathrm{Cu}, \mathrm{Fe}, \mathrm{P}, \mathrm{Mn}, \mathrm{S}$, and $\mathrm{Zn}$ that are also known to be essential for optimal animal performance (NRC 1996).

Diploid Russian wildrye genotypes have been used in most grazing and nutritive quality research, but stands of this forage are often difficult to establish. Induced autotetraploid Russian wildrye developed by Berdahl and Barker (1991) has been reported to have superior seedling vigor, and natural tetraploids recently obtained from Kazakhstan were reported to have heavier seeds, greater seedling vigor, were slightly taller and had longer and wider leaves than diploid genotypes (Asay et al. 1996). Generally, water stressed forages have higher nutritive quality (Crasta and Cox 1996, Deetz et al. 1996), primarily because of increased leaf-to-stem ratios (Halim et al. 1990), but less is known about the effect of water stress on plant mineral concentrations. Nitrogen fertilizer usually increases plant crude protein concentrations (Perry and Baltensperger 1979), but its affect on other elements is less well known.

Numerous studies have shown that both sheep (Ovis aries) and cattle (Bos taurus) voluntarily consume more leaves than stems (Minson 1990), indicating the need to determine how essential mineral levels differ between leaf and stem tissues, and whether differences are affected by stage of maturity. The potential value of Russian wildrye for early and late grazing, coupled with its reputation as a tetany prone forage suggested a need to determine how some common natural and management situations would affect the concentration of minerals critical to animal production. In the northern plains, drought is a common natural occurrence and $\mathrm{N}$ fertilization is a common management practice, thus the effect of water or lack of water, and $\mathrm{N}$ fertilizer on forage mineral concentrations were logical treatments needing further study. The effect of ploidy level on forage mineral concentrations is important because of the recent introduction of tetraploid Russian wildrye, which has some desirable agronomic characteristics, but virtually nothing is known about its chemical composition. Thus, research was undertaken to determine the effect of ploidy, water, and fertilizer $\mathrm{N}$ levels on Russian wildrye tissue mineral concentrations at 4 stages of maturity, when plants were grown in a field environment using a rain shelter where water levels could be controlled. A secondary objective was to determine the effect of these variables on mineral levels essential for optimal beef cattle production.

\section{Materials and Methods}

Diploid and tetraploid populations of Russian wildrye were seeded in 1993 in plots containing 8 rows (3.6-m length, $0.33 \mathrm{~m}$ between rows) of plants, grown in a field environment under a movable rain shelter (Ries and Zachmeier 1985), that automatically covered the plots when activated by precipitation. Plots were located near Mandan, N.D. $\left(46^{\circ} 46^{\prime} \mathrm{N}, 100^{\circ} 55^{\prime}\right.$ $\mathrm{W})$. The seeding rate was 90 seeds $\mathrm{m}^{-1}$ of row length (Frank and Berdahl 2001). The movable rain shelter allowed precise application of water treatments to the plots by an overhead sprinkler system. The 2 populations included the diploid cultivar Vinall, which has been used as a standard in many Russian wildrye studies, and a tetraploid population which was a balanced composite of 6 populations, representative of tetraploid germplasm in the Mandan breeding program (Frank and Berdahl 2001). Soil was a Parshall fine sandy loam (coarse-loamy, mixed superactive, frigid, pachic Haplustolls).

There were 4 replicates of each population arranged in a split-split plot design. Main plots were water treatments, with $\mathrm{N}$ levels and populations as subplots. Water treatments provided 50 and $150 \%$ of the long-term average monthly precipitation for April through October at Mandan. Long-term averages ( $30 \mathrm{yr}$ ) were based on precipitation levels of $38,55,85,61,43$, 38, and $24 \mathrm{~mm}$ for April, May, June, July, August, September, and October, respec- tively (Frank and Berdahl 1999). Treatment levels were achieved by 1 watering event per week. From November through March each year, plots were exposed to actual winter precipitation. Nitrogen treatments were randomly applied within water treatment and population in April of each year, using ammonium nitrate fertilizer at $2 \mathrm{lev}$ els: low (10) and high (134 kg N ha ${ }^{-1}$ ). Water and $\mathrm{N}$ treatments were initiated in 1993 to ensure that plants were acclimated to their respective treatments, before data collection was initiated in 1994. The study contained a total of 32 plots from 4 replications of 2 ploidy levels, 2 water levels, and $2 \mathrm{~N}$ levels.

Forage samples were collected from plots for nutritive quality analysis at the vegetative, boot, anthesis, and anthesis plus 10-day stages of maturity in 1994, 1995 and 1996. Forages began to grow at different times each year due to variation in accumulated growing degree days; thus, sampling dates were not consistent among years. In 1994, samples were harvested on 4, 16, and 31 May, and 14 June. In 1995, samples were harvested on 10 and 22 May, and 6 and 21 June. In 1996, samples were harvested on 17 and 28 May, and 14 and 26 June. Within years, forage samples were harvested from a different portion of the plot at each sampling date. In September of each year all plots were clipped to a similar height to minimize potential plot effects the following year.

Harvested samples were rinsed in distilled water to remove any contaminating soil, and dried to a constant weight at $55^{\circ}$ $\mathrm{C}$ in a forced-air oven. All samples were ground through a 1-mm screen before analysis. Samples collected at anthesis and anthesis plus 10-day stages of maturity were separated into leaf, stem and inflorescence tissue before being ground. Inflorescence samples were not analyzed for this study because sample material was limited. Forage samples obtained at vegetative and boot stages of maturity were primarily leaf tissue. Samples were analyzed for $\mathrm{P}, \mathrm{Ca}, \mathrm{K}, \mathrm{Mg}, \mathrm{S}, \mathrm{Cu}, \mathrm{Zn}, \mathrm{Mn}, \mathrm{Fe}$, aluminum $(\mathrm{Al})$ and sodium $(\mathrm{Na})$ using a plasma emission spectrophotometer.

Data were analyzed using the SAS MIXED procedure (SAS Inst., Inc. 1996) with ploidy, water and $\mathrm{N}$ levels fixed and replication, replication $\mathrm{x}$ water level, and replication $\mathrm{x}$ water $\mathrm{x}$ ploidy $\mathrm{x} \mathrm{N}$ level considered random. Years were treated as repeated measures. Least-squares means for ploidy, water, and $\mathrm{N}$ levels were separated by an F-test and means for stage of maturity were separated by the SAS PDIFF option. Data comparisons were considered significant at $\mathrm{P}<0.05$. 
Table 1. Main effect and interaction probabilities for leaf tissue minerals of 2 ploidy levels of Russian wildrye, grown at 2 water levels and 2 fertilizer levels over 3 growing seasons.

\begin{tabular}{|c|c|c|c|c|c|c|c|c|c|c|c|}
\hline Effect & $\mathbf{P}$ & $\mathrm{Ca}$ & $\mathrm{K}$ & $\mathrm{Mg}$ & $\mathrm{S}$ & $\begin{array}{c}\text { Mineral } \\
\mathrm{Na}\end{array}$ & $\mathrm{Cu}$ & $\mathrm{Zn}$ & Mn & $\mathrm{Fe}$ & $\mathrm{Al}$ \\
\hline Ploidy level & 0.06 & $<0.01$ & 0.34 & $<0.01$ & 0.58 & $<0.01$ & 0.65 & 0.21 & $<0.01$ & 0.29 & 0.13 \\
\hline Water level & $<0.01$ & 0.13 & 0.09 & 0.24 & 0.01 & 0.12 & 0.10 & 0.46 & $<0.01$ & 0.09 & 0.19 \\
\hline Nitrogen level & $<0.01$ & $<0.01$ & $<0.01$ & 0.41 & $<0.01$ & $<0.01$ & $<0.01$ & $<0.01$ & 0.18 & 0.05 & 0.03 \\
\hline Ploidy $\mathrm{x}$ water & 0.44 & 0.13 & 0.55 & 0.06 & 0.16 & 0.76 & 0.59 & 0.80 & 0.42 & 0.56 & 0.21 \\
\hline Ploidy $\mathrm{x}$ nitrogen & 0.55 & 0.54 & 0.14 & 0.41 & 0.05 & 0.77 & 0.10 & 0.20 & 0.92 & 0.96 & 0.69 \\
\hline Water $\mathrm{x}$ nitrogen & $<0.01$ & 0.73 & 0.10 & 0.38 & $<0.01$ & 0.23 & 0.05 & 0.90 & 0.91 & 0.41 & 0.87 \\
\hline Ploidy $\mathrm{x}$ water $\mathrm{x}$ nitrogen & 0.55 & 0.65 & 0.54 & 0.19 & 0.85 & 0.28 & 0.49 & 0.84 & 0.83 & 0.23 & 0.28 \\
\hline Harvest date (HD) & $<0.01$ & $<0.01$ & $<0.01$ & $<0.01$ & $<0.01$ & $<0.01$ & $<0.01$ & $<0.01$ & $<0.01$ & $<0.01$ & $<0.01$ \\
\hline HD x ploidy & 0.44 & $<0.01$ & 0.02 & 0.04 & 0.19 & 0.27 & 0.97 & 0.18 & 0.06 & 0.44 & 0.13 \\
\hline HD x water & $<0.01$ & $<0.01$ & $<0.01$ & $<0.01$ & 0.88 & 0.97 & 0.99 & 0.26 & $<0.01$ & 0.05 & $<0.01$ \\
\hline HD $x$ nitrogen & 0.12 & $<0.01$ & 0.70 & 0.05 & $<0.01$ & 0.10 & 0.06 & 0.99 & $<0.01$ & 0.08 & $<0.01$ \\
\hline
\end{tabular}

\section{Results}

Statistical probabilities of main effects and interaction effects are summarized in Table 1 for leaf tissue and Table 2 for stem tissue. Data are presented by main effect, in the following order: ploidy level, water treatment level, $\mathrm{N}$ fertilizer, and harvest date. centrations were $0.26,0.23,0.38$, and $0.42 \%$ and tetraploid $\mathrm{Ca}$ concentrations were $0.24,0.22,0.33$, and $0.36 \%$ for vegetative, boot, anthesis, and anthesis plus 10day harvest dates, respectively. Significant ploidy level $\mathrm{x}$ harvest date interactions for leaf $\mathrm{Ca}$ and $\mathrm{Mg}$ (Table 1 and Fig. $1 \mathrm{~A}, \mathrm{~B}$ ) were due to greater mineral concentration differences between diploid and tetraploid
Tetraploid plants had higher stem $P$ concentrations than diploid plants, but diploid plants had higher $\mathrm{Ca}, \mathrm{K}, \mathrm{Na}$, and $\mathrm{Mn}$ concentrations (Table 3 ). The only ploidy level interaction with these minerals in stem tissue was with water level (Table 2 and Fig. 1C). Diploid and tetraploid stem $\mathrm{P}$ did not differ at the $50 \%$ water level, but at the $150 \%$ water level, tetraploid plants were slightly higher in $\mathrm{P}$ than diploid

Table 2. Main effect and interaction probabilities for stem tissue minerals of 2 ploidy levels of Russian wildrye, grown at 2 water levels and $2 \mathrm{~N}$ fertilizer levels over 3 growing seasons.

\begin{tabular}{|c|c|c|c|c|c|c|c|c|c|c|c|}
\hline Effect & $\mathrm{P}$ & $\mathrm{Ca}$ & $\mathrm{K}$ & $\mathrm{Mg}$ & $\mathrm{S}$ & $\begin{array}{c}\text { Mineral } \\
\mathrm{Na}\end{array}$ & $\mathrm{Cu}$ & $\mathrm{Zn}$ & $\mathrm{Mn}$ & $\mathrm{Fe}$ & $\mathrm{Al}$ \\
\hline Ploidy level & 0.02 & $<0.01$ & 0.03 & 0.53 & 0.27 & 0.01 & 0.57 & 0.27 & 0.02 & 0.91 & 0.38 \\
\hline Water level & $<0.01$ & 0.39 & 0.93 & 0.45 & 0.01 & 0.63 & 0.80 & 0.10 & 0.04 & 0.06 & 0.38 \\
\hline Nitrogen level & $<0.01$ & $<0.01$ & $<0.01$ & $<0.01$ & $<0.01$ & 0.14 & $<0.01$ & $<0.01$ & 0.72 & 0.37 & 0.02 \\
\hline Ploidy $\mathrm{x}$ water & 0.04 & 0.55 & 0.19 & 0.86 & 0.76 & 0.45 & 0.51 & 0.40 & 0.97 & 0.72 & 0.33 \\
\hline Ploidy $\mathrm{x}$ nitrogen & 0.72 & 0.57 & 0.72 & 0.59 & 0.15 & 0.47 & 0.66 & 0.71 & 0.90 & 0.69 & 0.40 \\
\hline Water $\mathrm{x}$ nitrogen & $<0.01$ & 0.26 & 0.13 & 0.09 & 0.27 & 0.44 & 0.58 & 0.67 & 0.54 & 0.38 & 0.23 \\
\hline Ploidy $\mathrm{x}$ water $\mathrm{x}$ nitrogen & 0.26 & 0.12 & 0.94 & 0.97 & 0.48 & 0.06 & 0.87 & 0.38 & 0.86 & 0.23 & 0.28 \\
\hline Harvest date (HD) & $<0.01$ & 0.01 & $<0.01$ & 0.36 & $<0.01$ & $<0.01$ & $<0.01$ & $<0.01$ & $<0.01$ & $<0.01$ & 0.38 \\
\hline HD x ploidy & 0.22 & 0.64 & 0.16 & 0.38 & 0.86 & 0.17 & 0.18 & 0.34 & 0.74 & 0.66 & 0.24 \\
\hline HD x water & 0.18 & 0.99 & 0.99 & 0.88 & 0.88 & 0.68 & 0.11 & 0.04 & 0.22 & 0.19 & 0.61 \\
\hline HD $x$ nitrogen & 0.27 & 0.10 & 0.50 & 0.39 & 0.06 & 0.47 & 0.03 & 0.32 & 0.90 & 0.62 & 0.10 \\
\hline
\end{tabular}

\section{Ploidy Level}

Calcium, $\mathrm{Mg}, \mathrm{Na}$, and $\mathrm{Mn}$ concentrations were higher in diploid than tetraploid leaf tissue (Table 3). Diploid leaf Ca con- leaf tissues at later harvest dates, but leaf $\mathrm{Ca}$ and $\mathrm{Mg}$ concentrations were still consistently higher in diploid than tetraploid tissues. plants. Ploidy level affected relatively few mineral concentrations and most differences were quite small, even when they were significant.

Table 3. Leaf and stem mineral concentrations in diploid and tetraploid Russian wildrye taxa. Values are mean and SE averaged over water level, $\mathbf{N}$ level and harvest date. ${ }^{1}$

\begin{tabular}{|c|c|c|c|c|c|c|c|c|c|c|c|}
\hline Ploidy level & $\mathrm{P}$ & $\mathrm{Ca}$ & K & $\mathrm{Mg}$ & $S$ & $\mathrm{Na}$ & $\mathrm{Cu}$ & $\mathrm{Zn}$ & $\mathrm{Mn}$ & $\mathrm{Fe}$ & $\mathrm{Al}$ \\
\hline \multicolumn{12}{|c|}{ ppm dry basis)----- } \\
\hline Diploid & 0.28 & $0.32^{\mathrm{a}}$ & 3.6 & $0.25^{\mathrm{a}}$ & 0.32 & $0.13^{\mathrm{a}}$ & 7 & 38 & $55^{\mathrm{a}}$ & 101 & 62 \\
\hline Tetraploid & 0.27 & $0.29^{b}$ & 3.6 & $0.23^{\mathrm{b}}$ & 0.33 & $0.11^{\mathrm{b}}$ & 7 & 37 & $50^{\mathrm{b}}$ & 95 & 59 \\
\hline SE & 0.01 & 0.01 & 0.1 & 0.00 & 0.01 & 0.01 & 0 & 2 & 1 & 6 & 2 \\
\hline \multicolumn{12}{|l|}{$\underline{\text { Stem tissue }}$} \\
\hline Diploid & $0.16^{\mathrm{b}}$ & $0.10^{\mathrm{a}}$ & $2.9^{\mathrm{a}}$ & 0.10 & 0.15 & $0.08^{\mathrm{a}}$ & 5 & 22 & $20^{\mathrm{a}}$ & 39 & 26 \\
\hline Tetraploid & $0.17^{\mathrm{a}}$ & $0.09^{b}$ & $2.7^{b}$ & 0.10 & 0.15 & $0.07^{\mathrm{b}}$ & 5 & 21 & $19^{\mathrm{b}}$ & 39 & 25 \\
\hline SE & 0.01 & 0.00 & 0.1 & 0.01 & 0.01 & 0.00 & 0 & 1 & 1 & 1 & 1 \\
\hline
\end{tabular}

${ }^{1}$ Means within a tissue type and mineral with different superscripts differ at $\mathrm{P}<0.05$. 

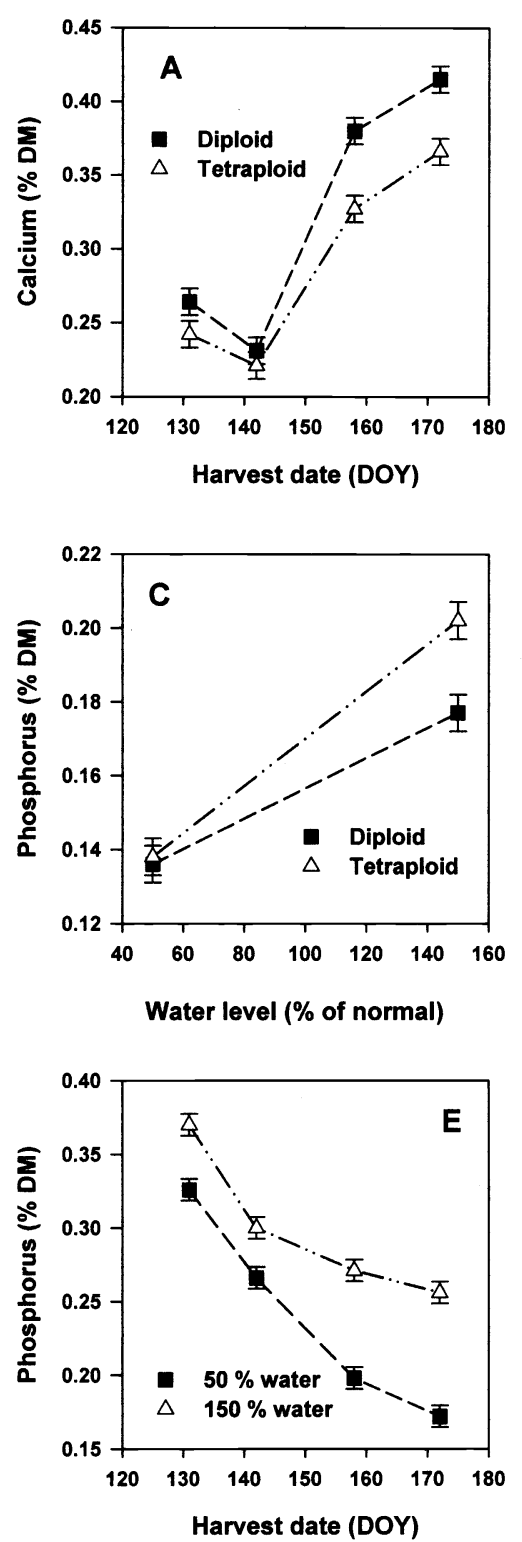

Fig. 1. Interaction effects of (A) ploidy and harvest date on leaf $\mathrm{Ca}$, (B) ploidy and harvest date on leaf $\mathrm{Mg}$, (C) ploidy and water level on stem $\mathbf{P}$ (D) water level and $\mathbf{N}$ fertilizer on leaf $P,(E)$ water level and harvest date on leaf $P$, and $(F)$ water and $N$ fertilizer level on leaf $S$.

Although mineral concentrations in leaf and stem tissues were not statistically compared, concentrations of $\mathrm{P}, \mathrm{Ca}, \mathrm{Mg}, \mathrm{S}$, $\mathrm{Zn}, \mathrm{Mn}, \mathrm{Fe}$, and $\mathrm{Al}$, in leaf tissue were 50 to $150 \%$ higher than levels in stem tissue. Potassium, $\mathrm{Na}$, and $\mathrm{Cu}$ concentrations were also higher in leaf tissue, but differences were not as great as they were for the other minerals (Table 3 ).
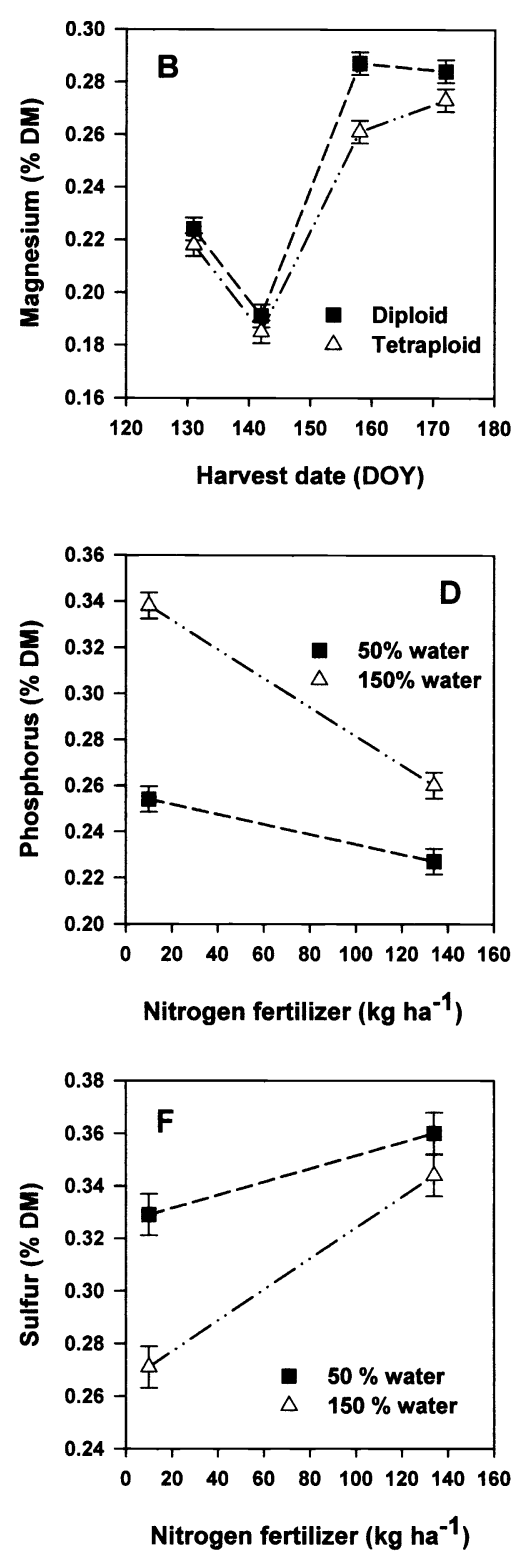

\section{Water Treatment}

Leaf tissue $\mathrm{P}, \mathrm{S}$ and $\mathrm{Mn}$ were significantly affected by water level, with the $150 \%$ water treatment resulting in the highest $\mathrm{P}$ concentrations, and the $50 \%$ water treatment resulting in the highest $\mathrm{S}$ and Mn levels (Table 4). However, water level effects on $\mathrm{P}$ were not consistent over the $2 \mathrm{~N}$ levels (Fig. 1D). Leaf $\mathrm{P}$ increased less between high and low $\mathrm{N}$ treatments at the $50 \%$ water level than at the $150 \%$ water level. There was also a water by harvest date interaction for leaf $\mathrm{P}$, where leaf $\mathrm{P}$ levels for the $50 \%$ water treatment were lower initially, and declined more rapidly between vegetative and anthesis plus 10day stages of maturity, than P levels for the $150 \%$ water treatment (Fig. 1E).

An interaction between water and $\mathrm{N}$ fertilizer levels for leaf $S$ (Fig. 1F) was due to the magnitude of the difference between $\mathrm{N}$ effects at $50 \%$ and $150 \%$ water levels, but $\mathrm{S}$ was higher in leaves from high $\mathrm{N}$ treatment plants for both water treatments. Differences in Mn concentrations in leaf tissue between 50 and $150 \%$ water treatments were not consistent over harvest dates creating an interaction (Fig. 2A). Manganese concentration differences between the 2 water treatments were greater at anthesis and anthesis plus 10day stages of maturity than at vegetative and boot stages, although Mn concentrations were always higher for the $50 \%$ water treatment.

Stem tissue concentrations of $\mathrm{P}$ were increased by the $150 \%$ water treatment, while Mn concentrations in stem tissue were higher in plants grown at the $50 \%$ water treatment, which is consistent with leaf tissue results (Table 4). Stem P levels at the $50 \%$ water treatment differed little between low and high $\mathrm{N}$ treatments, but at the $150 \%$ water treatment $P$ concentrations were substantially higher at the low than at the high $\mathrm{N}$ treatment, resulting in a significant interaction (Fig. 2B). Mineral concentrations in either Russian wildrye leaf or stem tissue were relatively unaffected by differences in growing season water levels.

\section{Nitrogen Fertilizer}

Nitrogen fertilizer had a greater affect than ploidy or water level on mineral concentrations in both Russian wildrye leaf and stem tissue, with 9 minerals affected in leaf tissue, and 8 in stem tissue (Table 5). Phosphorus levels in leaf tissue were decreased by $\mathrm{N}$ fertilization, but $\mathrm{Ca}, \mathrm{K}, \mathrm{S}$, $\mathrm{Na}, \mathrm{Cu}, \mathrm{Zn}, \mathrm{Fe}$, and $\mathrm{Al}$ concentrations were all increased (Table 5). In leaf tissue, only $\mathrm{Mg}$ and $\mathrm{Mn}$ concentrations were unaffected by $\mathrm{N}$ fertilizer.

Water and $\mathrm{N}$ treatments interacted with regard to leaf $\mathrm{Cu}$ (Fig. 2C), with the 50 and $150 \%$ water treatments having the same leaf $\mathrm{Cu}$ concentration at the low $\mathrm{N}$ level $\left(10 \mathrm{~kg} \mathrm{ha}^{-1}\right)$, while at the high $\mathrm{N}$ level $\left(134 \mathrm{~kg} \mathrm{ha}^{-1}\right)$ leaf $\mathrm{Cu}$ was slightly greater for the $150 \%$ water treatment. Significant interactions also existed between harvest date and $\mathrm{N}$ level, for leaf Ca (Fig. 2D), S, and $\mathrm{Al}$ (Table 1). Calcium levels were the same for high and low $\mathrm{N}$ treatments at the 
Table 4. Leaf and stem mineral concentrations in Russian wildrye grown at 2 water levels. Values are mean and SE averaged over ploidy level, $\mathbf{N}$ level and harvest date. 1

\begin{tabular}{|c|c|c|c|c|c|c|c|c|c|c|c|}
\hline Water level & $\mathrm{P}$ & $\mathrm{Ca}$ & $\mathrm{K}$ & $\mathrm{Mg}$ & $\mathrm{S}$ & $\mathrm{Na}$ & $\mathrm{Cu}$ & $\mathrm{Zn}$ & $\mathrm{Mn}$ & $\mathrm{Fe}$ & $\mathrm{Al}$ \\
\hline Leaf Tissue & 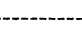 & .-. &.-- & DM)-- & $\ldots$ & --.---. & $\ldots$ & - & n dry & - & ---- \\
\hline $\begin{array}{r}50 \% \text { of ave. } \\
150 \% \text { of ave. } \\
\text { SE }\end{array}$ & $\begin{array}{l}0.24^{\mathrm{b}} \\
0.30^{\mathrm{a}} \\
0.01\end{array}$ & $\begin{array}{l}0.32 \\
0.29 \\
0.01\end{array}$ & $\begin{array}{l}3.7 \\
3.6 \\
0.1\end{array}$ & $\begin{array}{l}0.24 \\
0.24 \\
0.00\end{array}$ & $\begin{array}{l}0.34^{\mathrm{a}} \\
0.31^{\mathrm{b}} \\
0.01\end{array}$ & $\begin{array}{l}0.12 \\
0.13 \\
0.01\end{array}$ & $\begin{array}{l}7 \\
7 \\
0\end{array}$ & $\begin{array}{r}38 \\
37 \\
2\end{array}$ & $\begin{array}{r}58^{\mathrm{a}} \\
47^{\mathrm{b}} \\
1\end{array}$ & $\begin{array}{r}106 \\
90 \\
6\end{array}$ & $\begin{array}{r}62 \\
59 \\
2\end{array}$ \\
\hline $\begin{array}{c}\text { Stem tissue } \\
50 \% \text { of ave. } \\
150 \% \text { of ave. } \\
\text { SE }\end{array}$ & $\begin{array}{l}0.14^{\mathrm{b}} \\
0.19^{\mathrm{a}} \\
0.01\end{array}$ & $\begin{array}{l}0.10 \\
0.10 \\
0.00\end{array}$ & $\begin{array}{l}2.8 \\
2.8 \\
0.1\end{array}$ & $\begin{array}{l}0.10 \\
0.10 \\
0.01\end{array}$ & $\begin{array}{l}0.16 \\
0.14 \\
0.01\end{array}$ & $\begin{array}{l}0.07 \\
0.08 \\
0.00\end{array}$ & $\begin{array}{l}5 \\
5 \\
0\end{array}$ & $\begin{array}{r}22 \\
20 \\
1\end{array}$ & $\begin{array}{c}21^{\mathrm{a}} \\
18^{\mathrm{b}} \\
1\end{array}$ & $\begin{array}{r}41 \\
37 \\
1\end{array}$ & $\begin{array}{r}26 \\
25 \\
1\end{array}$ \\
\hline
\end{tabular}

${ }^{1}$ Means within a tissue type and mineral with different superscripts differ at $\mathrm{P}<0.05$.

first harvest date, but levels were slightly greater at the high $\mathrm{N}$ treatment for the other 3 harvest dates. Leaf $\mathrm{S}$ was greater for the high $\mathrm{N}$ treatment at all 4 harvest dates, and the magnitude of this difference increased from vegetative to anthesis plus 10-day harvest dates.

Stem $P$ levels were also decreased at the high $\mathrm{N}$ level while $\mathrm{Ca}, \mathrm{K}, \mathrm{Mg}, \mathrm{S}, \mathrm{Cu}, \mathrm{Zn}$, and $\mathrm{Al}$ increased (Table 5). In contrast to leaf $\mathrm{Mg}$, stem $\mathrm{Mg}$ was slightly but significantly increased by $\mathrm{N}$ fertilizer, while $\mathrm{Na}$, $\mathrm{Mn}$, and $\mathrm{Fe}$ were unaffected by $\mathrm{N}$ levels. Stem $\mathrm{Cu}$ was higher at anthesis than anthesis plus 10 days, and differences between $\mathrm{N}$ treatments were also greater at anthesis, causing a significant interaction (Fig. 2E).

\section{Harvest Date}

Concentrations of all 11 minerals in leaf tissue were significantly affected by harvest date, and all minerals except $\mathrm{Mg}$ and $\mathrm{Al}$ were affected by harvest date in stem tissue (Table 6). Leaf $P$ and $\mathrm{Zn}$ levels decreased from vegetative to anthesis plus 10-day stages of maturity, and stem $P$ and $\mathrm{Zn}$ declined between anthesis and anthesis plus 10 days. Copper concentrations tended to decline as maturity advanced in both leaf and stem tissue. Calcium, $\mathrm{Mg}, \mathrm{Na}$, and $\mathrm{Al}$ concentrations in leaf tissue declined from vegetative to boot stages, then increased at anthesis and anthesis plus 10-day stages of maturity. Potassium, $\mathrm{S}, \mathrm{Mn}$, and Fe were less consistently affected by stage of maturity. Stem tissue $\mathrm{K}, \mathrm{S}, \mathrm{Mn}$, and Fe declined significantly between anthesis and anthesis plus 10 days, while $\mathrm{Ca}$ and $\mathrm{Na}$ increased slightly (Table 6). Stem tissue had fewer harvest date interactions, but there was a harvest date $\mathrm{x}$ water level interaction for $\mathrm{Zn}$ (Fig. $2 \mathrm{~F})$. Stem $\mathrm{Zn}$ at anthesis was higher for both the 50 and $150 \%$ water levels, but $\mathrm{Zn}$ concentration differences between anthesis and anthesis plus 10 days was greater for the $50 \%$ water treatment.

\section{Discussion}

\section{Ploidy Level}

Few differences in mineral concentration occurred between diploid and tetraploid Russian wildrye leaf and stem tissue, but most differences although small favored diploid plants. 'Ruff' a diploid crested wheatgrass cultivar was reported by Vogel et al. (1993) to generally have higher forage quality than 'Nordan', a tetraploid cultivar, although 'Nordan supported higher steer weight gains. Little previous nutritive quality data are avail- able on the tetraploid germplasm used in this study (Berdahl and Barker 1991). Since improvement in seedling vigor was an important selection criteria for this genetic material (Berdahl and Ries 1997), it is fortuitous that mineral concentrations in the new tetraploid germplasm was not adversely affected in the breeding and selection process. Although in this study genetic differences in mineral levels were small, breeding and selection efforts to reduce the incidence of grass tetany, by improving $\mathrm{Mg}$ concentrations in tall fescue (Reeder et al. 1986, Sleper et al. 1989), annual ryegrass (Hides and Thomas 1981) and Russian wildrye (Jefferson et al. 2001) have been encouraging.

\section{Water Treatment}

Water stress has been shown to have a positive (Vough and Marten 1971, Wilson 1983, Crasta and Cox 1996), negative (Wilson and $\mathrm{Ng} \mathrm{1975),} \mathrm{or} \mathrm{variable} \mathrm{(Halim}$ et al. 1989) effect on forage quality. Most water stress data concerns IVDDM, ADF, NDF or $\mathrm{N}$ differences in alfalfa (Vough and Marten 1971, Halim et al. 1989, and Deetz et al. 1996) or annual crops (Crasta and Cox 1996). Data assessing the effect of water stress on forage mineral levels is negligible (Buxton and Fales 1994). In this study, growing-season water levels only

Table 5. Leaf and stem mineral concentrations in Russian wildrye grown at $2 \mathrm{~N}$ fertilizer rates. Values are mean and SE averaged over ploidy level, water level and harvest date.

\begin{tabular}{|c|c|c|c|c|c|c|c|c|c|c|c|}
\hline Nitrogen & $\mathrm{P}$ & $\mathrm{Ca}$ & $\mathrm{K}$ & $\mathrm{Mg}$ & $S$ & $\mathrm{Na}$ & $\mathrm{Cu}$ & $\mathrm{Zn}$ & $\mathrm{Mn}$ & $\mathrm{Fe}$ & $\mathrm{Al}$ \\
\hline & \multicolumn{7}{|c|}{ Leaf Tissue } & --- & & -------- & --- \\
\hline$\frac{\text { Leaf Tissue }}{10 \mathrm{~kg} \mathrm{ha}^{-1}}$ & $0.30^{\mathrm{a}}$ & $0.29^{\mathrm{b}}$ & $3.5^{\mathrm{b}}$ & 0.24 & $0.30^{\mathrm{b}}$ & $0.11^{\mathrm{b}}$ & $7^{\mathrm{b}}$ & $36^{\mathrm{b}}$ & 54 & $92^{b}$ & $58^{\mathrm{b}}$ \\
\hline $134 \mathrm{~kg} \mathrm{ha}^{-1}$ & $0.24^{\mathrm{b}}$ & $0.32^{\mathrm{a}}$ & $3.7^{\mathrm{a}}$ & 0.24 & $0.35^{\mathrm{a}}$ & $0.13^{\mathrm{a}}$ & $8^{\mathrm{a}}$ & $39^{\mathrm{a}}$ & 52 & $104^{\mathrm{a}}$ & $62^{\mathrm{a}}$ \\
\hline $\mathrm{SE}$ & 0.01 & 0.01 & 0.1 & 0.00 & 0.01 & 0.01 & 0 & 2 & 1 & 6 & 2 \\
\hline \multicolumn{12}{|l|}{$\underline{\text { Stem tissue }}$} \\
\hline $10 \mathrm{~kg} \mathrm{ha}^{-1}$ & $0.18^{\mathrm{a}}$ & $0.09^{\mathrm{b}}$ & $2.6^{\mathrm{b}}$ & $0.10^{\mathrm{b}}$ & $0.13^{\mathrm{b}}$ & 0.07 & $5^{b}$ & $19^{\mathrm{b}}$ & 20 & 38 & $24^{b}$ \\
\hline $134 \mathrm{~kg} \mathrm{ha}^{-1}$ & $0.14^{b}$ & $0.11^{\mathrm{a}}$ & $3.0^{\mathrm{a}}$ & $0.11^{\mathrm{a}}$ & $0.17^{\mathrm{a}}$ & 0.08 & $6^{\mathrm{a}}$ & $23^{\mathrm{a}}$ & 20 & 40 & $27^{\mathrm{a}}$ \\
\hline SE & 0.01 & 0.00 & 0.1 & 0.01 & 0.01 & 0.00 & 0 & 1 & 1 & 1 & 1 \\
\hline
\end{tabular}

${ }^{1}$ Means within a tissue type and mineral with different superscripts differ at $\mathrm{P}<0.05$. 

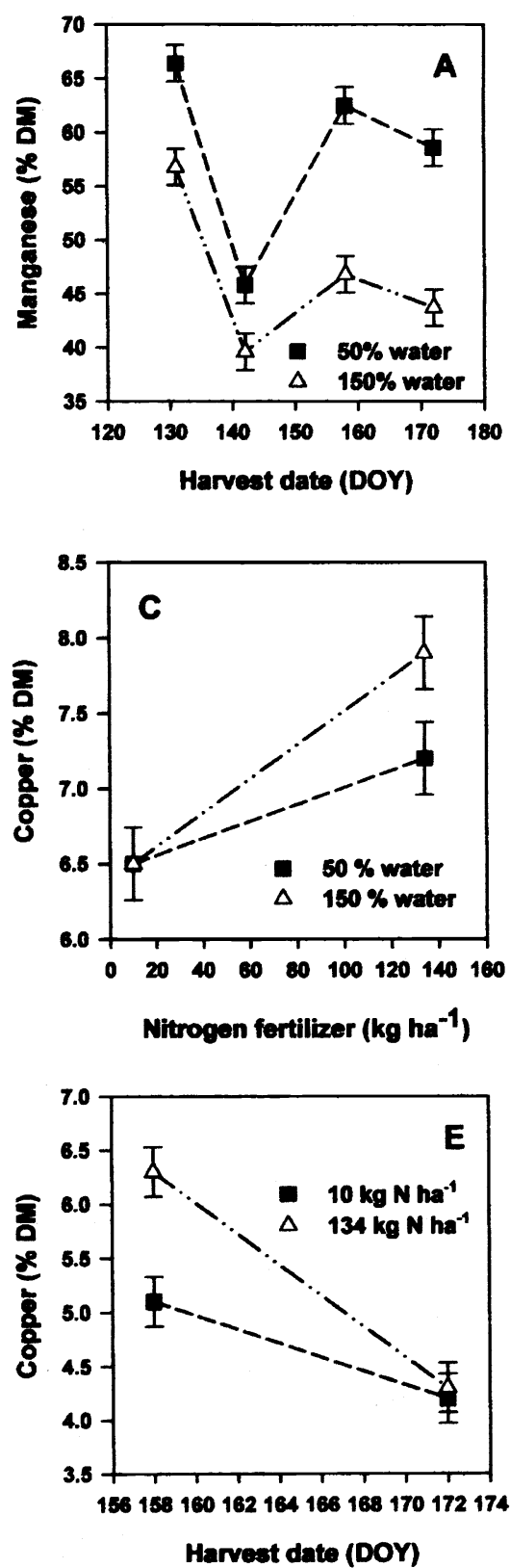

Fig. 2. Interaction effects of $(A)$ water and harvest date on leaf $M n,(B)$ water and $N$ fertilizer level on stem $P$ (C) water and $\mathbf{N}$ fertilizer level on leaf $\mathrm{Cu}$, (D) $\mathbf{N}$ fertilizer and harvest date on leaf $\mathrm{Ca},(\mathrm{E}) \mathrm{N}$ fertilizer and harvest date on stem $\mathrm{Cu}$, and (F) water level and harvest date on stem $\mathbf{Z n}$.

affected concentrations of $\mathrm{P}, \mathrm{S}$, and $\mathrm{Mn}$ in leaf tissue and $\mathrm{P}$ and $\mathrm{Mn}$ in stem tissue. The increased phosphorus levels in both leaf $(25 \%)$ and stem $(38 \%)$ tissue that occurred with higher water levels $(150 \%$ of average) is particularly important, because $\mathrm{P}$ is generally considered to be deficient for much of the world's grazing livestock (Church et al. 1971). These results are also encouraging because an increase in growing-season water in a semi-arid environment should increase forage yield which often results in a dilution of mineral concentrations. In a previ-

Harvest date (DOY)
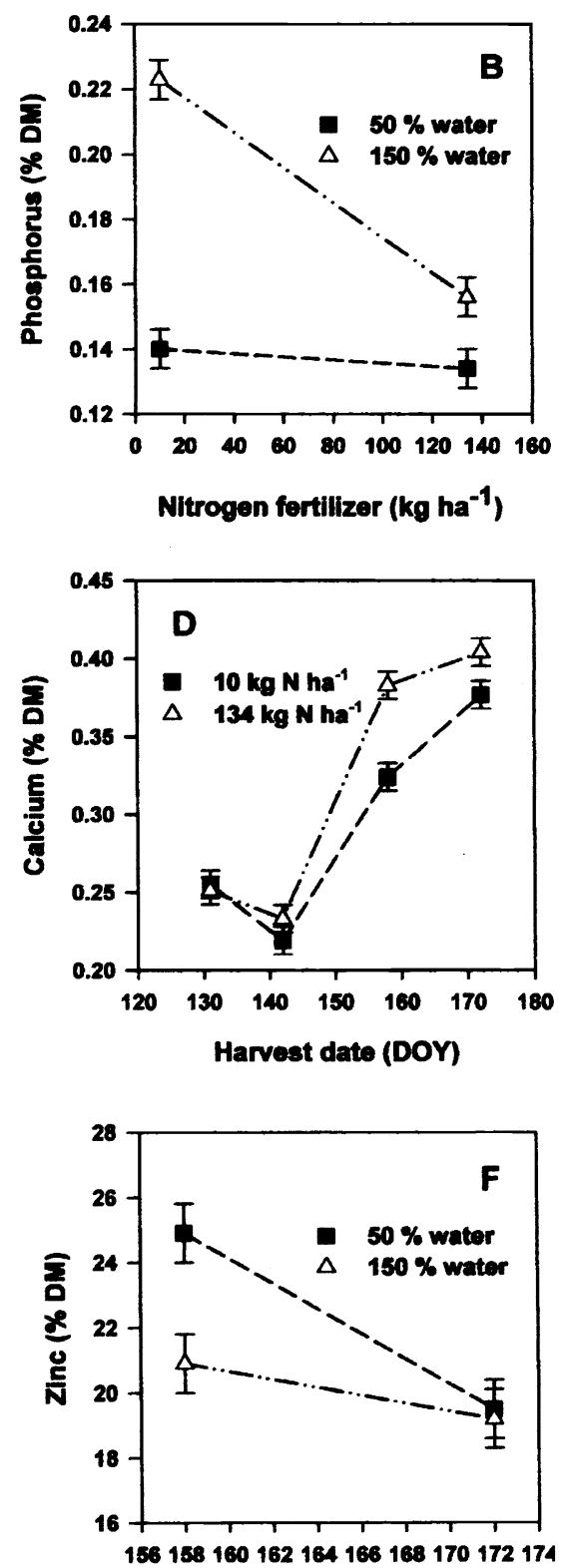

\section{Harvest Date}

Phosphorus levels in both leaf and stem tissues were adequate (NRC 1996) for beef cows and yearling steers during most phases of their lives. However, stem tissue $P$ levels at anthesis plus 10 days were not adequate for beef cows in early lactation (Table 6). Beef cow $\mathrm{Ca}$ needs could have been met by leaf tissue at anthesis or anthesis plus 10 days, but at vegetative and boot stages of maturity $\mathrm{Ca}$ would have been inadequate for high milking beef cows in early lactation. Stem tissue $\mathrm{Ca}$ was very low (about $0.10 \%$ ), indicating that if Russian wildrye hay contained $50 \%$ or more stem tissue, it would not be adequate in $\mathrm{Ca}$ for even moderately milking beef cows (NRC 1996).

Magnesium in leaf tissue ranged from $0.19-0.28 \%$. It has been suggested that 
Table 6. Leaf and stem mineral concentrations in Russian wildrye harvested at different stages of maturity. Values are mean and SE averaged over ploidy, water, and $\mathrm{N}$ level. ${ }^{1}$

\begin{tabular}{|c|c|c|c|c|c|c|c|c|c|c|c|}
\hline Maturity stage & $\mathrm{P}$ & $\mathrm{Ca}$ & $\mathrm{K}$ & $\mathrm{Mg}$ & $S$ & $\mathrm{Na}$ & $\mathrm{Cu}$ & $\mathrm{Zn}$ & $\mathrm{Mn}$ & $\mathrm{Fe}$ & $\mathrm{Al}$ \\
\hline Leaf Tissue & 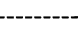 & $-\cdots$ & $\cdots$ & DI & 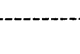 & -------- & $\cdots$ & ---- & dry & - & --- \\
\hline $\begin{array}{l}\text { Vegetative } \\
\text { Boot } \\
\text { Anthesis } \\
\text { Anthesis + } 10 \mathrm{~d} \text {. } \\
\quad \text { SE }\end{array}$ & $\begin{array}{l}0.35^{\mathrm{a}} \\
0.28^{\mathrm{b}} \\
0.23^{\mathrm{c}} \\
0.21^{\mathrm{d}} \\
0.01\end{array}$ & $\begin{array}{l}0.25^{\mathrm{c}} \\
0.23^{\mathrm{d}} \\
0.35^{\mathrm{b}} \\
0.39^{\mathrm{a}} \\
0.01\end{array}$ & $\begin{array}{l}3.7^{\mathrm{b}} \\
3.7^{\mathrm{b}} \\
3.9^{\mathrm{a}} \\
3.2^{\mathrm{c}} \\
0.1\end{array}$ & $\begin{array}{l}0.22^{\mathrm{b}} \\
0.19^{\mathrm{c}} \\
0.27^{\mathrm{a}} \\
0.28^{\mathrm{a}} \\
0.00\end{array}$ & $\begin{array}{l}0.36^{\mathrm{a}} \\
0.29^{\mathrm{d}} \\
0.32^{\mathrm{c}} \\
0.34^{\mathrm{b}} \\
0.01\end{array}$ & $\begin{array}{l}0.10^{\mathrm{b}} \\
0.09^{\mathrm{b}} \\
0.14^{\mathrm{a}} \\
0.14^{\mathrm{a}} \\
0.01\end{array}$ & $\begin{array}{l}8^{\mathrm{a}} \\
7^{\mathrm{b}} \\
7^{\mathrm{b}} \\
6^{\mathrm{c}} \\
0\end{array}$ & $\begin{array}{c}45^{\mathrm{a}} \\
40^{\mathrm{b}} \\
37^{\mathrm{b}} \\
30^{\mathrm{c}} \\
2\end{array}$ & $\begin{array}{c}62^{\mathrm{a}} \\
43 \mathrm{~d} \\
55^{\mathrm{b}} \\
51^{\mathrm{c}} \\
1\end{array}$ & $\begin{array}{r}106^{\mathrm{b}} \\
63^{\mathrm{d}} \\
89^{\mathrm{c}} \\
136^{\mathrm{a}} \\
7\end{array}$ & $\begin{array}{r}57^{\mathrm{c}} \\
41^{\mathrm{d}} \\
63^{\mathrm{b}} \\
80^{\mathrm{a}} \\
2\end{array}$ \\
\hline $\begin{array}{l}\frac{\text { Stem tissue }}{\text { Anthesis }} \\
\text { Anthesis }+10 \mathrm{~d} . \\
\quad \text { SE }\end{array}$ & $\begin{array}{l}0.18^{\mathrm{a}} \\
0.15^{\mathrm{b}} \\
0.01\end{array}$ & $\begin{array}{l}0.09^{\mathrm{b}} \\
0.10^{\mathrm{a}} \\
0.00\end{array}$ & $\begin{array}{l}3.0^{\mathrm{a}} \\
2.6^{\mathrm{b}} \\
0.1\end{array}$ & $\begin{array}{l}0.10 \\
0.10 \\
0.01\end{array}$ & $\begin{array}{l}0.16^{\mathrm{a}} \\
0.14^{\mathrm{b}} \\
0.01\end{array}$ & $\begin{array}{l}0.07^{\mathrm{b}} \\
0.08^{\mathrm{a}} \\
0.00\end{array}$ & $\begin{array}{l}6^{\mathrm{a}} \\
4^{\mathrm{b}} \\
0\end{array}$ & $\begin{array}{c}23^{\mathrm{a}} \\
19^{\mathrm{b}} \\
1\end{array}$ & $\begin{array}{c}22^{\mathrm{a}} \\
18^{\mathrm{b}} \\
1\end{array}$ & $\begin{array}{c}42^{\mathrm{a}} \\
36^{\mathrm{b}} \\
1\end{array}$ & $\begin{array}{r}26 \\
25 \\
1\end{array}$ \\
\hline
\end{tabular}

${ }^{1}$ Means within a tissue type and mineral with different superscripts differ at $\mathrm{P}<0.05$.

forage $\mathrm{Mg}$ levels above $0.2 \%$ should be adequate to prevent grass tetany (Kemp 1960). However, $\mathrm{Mg}$ levels may need to be substantially above $0.2 \%$ when forage $\mathrm{K}$ levels exceed $3.25 \%$ (Metson et al. 1966). Although $\mathrm{Mg}$ in Russian wildrye leaf tissue exceeded $0.19 \%$ at all stages of maturity, leaf $\mathrm{K}$ levels ranged from 3.25 to $3.89 \%$ suggesting that $\mathrm{Mg}$ levels may have been inadequate to prevent grass tetany at some stages of maturity. The lowest levels of $\mathrm{Mg}$ occurred at the vegetative and boot stages when $\mathrm{K}$ was near $3.7 \%$ (Table 6). In comparison, at anthesis $\mathrm{Mg}$ in stem tissue was only $0.1 \%$, while $\mathrm{K}$ was near $3.0 \%$. It would appear that Russian wildrye on a whole plant basis, would have been marginal in $\mathrm{Mg}$ at all stages of maturity.

Sulfur concentrations in both leaf and stem tissue were at or above levels indicated by McDowell (1997) to be adequate for lactating and growing and finishing cattle. Forage copper levels ranging from 4-6 ppm, with molybdenum (Mo) concentrations below $1.5 \mathrm{ppm}$ provided adequate $\mathrm{Cu}$ for cattle in western Australia, but in England, cattle grazing pastures with $\mathrm{Cu}$ concentrations of 7-14 ppm and Mo concentrations of 3-20 ppm responded to $\mathrm{Cu}$ therapy (Underwood 1977). Copper requirements reported by the NRC (1996) are $10 \mathrm{ppm}$ for cattle in all stages of production. Copper concentrations in Russian wildrye leaf tissue were below $10 \mathrm{ppm}$, but may have been adequate for all classes of beef cattle, since molybdenum concentrations were below $1.0 \mathrm{ppm}$ (data not shown). Copper concentrations in stem tissue were more marginal. The NRC (1996) recommends $30 \mathrm{ppm} \mathrm{Zn}$ and $50 \mathrm{ppm} \mathrm{Fe}$ for all classes of beef cattle. These recommendations were easily met by leaf tissue, but were inadequate in stem tissue (Table 6). The $\mathrm{Mn}$ recommendation for growing and finishing cattle is $20 \mathrm{ppm}$; both leaf and stem tissue met or exceeded this level.
However, the $\mathrm{Mn}$ recommendation for gestating and lactating cows is $40 \mathrm{ppm}$ (NRC 1996). Leaf tissue easily met this recommendation, while stem tissue would provide only about half of the recommended level (Table 6).

\section{Conclusion}

Ploidy level resulted in small and relatively minor differences in mineral concentrations in Russian wildrye leaves and stems. This was a beneficial finding, because the tetraploid germplasm was developed without consideration of potential breeding and selection effects on forage quality. Growing-season water level also had minimal effects on mineral concentrations, except for $\mathrm{P}$ which was apparently enhanced by higher soil water. Nitrogen fertilizer had both positive and negative effects on forage mineral levels. For example, positive effects include slightly higher levels of $\mathrm{Ca}, \mathrm{Cu}$, and $\mathrm{Zn}$, and negative effects included lower $\mathrm{P}$, which is always detrimental to forage fed animals. Higher $\mathrm{K}$ concentrations associated with $\mathrm{N}$ fertilizer would exacerbate a potential grass tetany problem. There were some important mineral changes due to maturity, with concentrations of $\mathrm{P}, \mathrm{Cu}$ and $\mathrm{Zn}$ tending to decline with maturity and $\mathrm{Ca}$ and $\mathrm{Mg}$ tending to increase. Phosphorus in whole plants at anthesis and anthesis plus 10 days and $\mathrm{Ca}$ and $\mathrm{Mg}$ at vegetative and boot stages would have been marginal for high milk producing beef cows during early lactation. Copper levels appear marginal at all stages of maturity in both leaves and stems. Nevertheless, if producers are aware of these potential mineral problems, the variables considered in this research should have little effect on the use of Russian wildrye for spring grazing.

\section{Literature Cited}

Asay, K.H. and H.F. Mayland. 1990. Genetic variability for elements associated with grass tetany in Russian wildrye. J. Range Manage. 43:407-410.

Asay, K.H., D.A. Johnson, K.B. Jensen, W. Sarraj, and D.H. Clark. 1996. Potential of new tetraploid germplasm in Russian wildrye. J. Range Manage. 49:439-442.

Berdahl, J.D. and R.E. Barker. 1991. Characterization of autotetraploid Russian wildrye produced with nitrous oxide. Crop Sci. 31:1153-1155.

Berdahl, J.D. and R.E. Ries. 1997. Development and vigor of diploid and tetraploid Russian wildrye seedlings. J. Range Manage. 50:80-84.

Buxton, D.R. and S.L. Fales. 1994. Plant environment and quality, p. 155-199. In: G.C. Fahey, Jr. (ed.) Forage quality, evaluation, and utilization. ASA, CSSA, SSSA, Madison, Wisc.

Church, D.C., G.E. Smith, J.P. Fontenot, and A.T. Ralston. 1971. Digestive physiology and nutrition of ruminants. Vol. 2 Albany Print. Co., Albany, Ore.

Committee on Mineral Nutrition. 1973. Tracing and treating mineral disorders in dairy cattle. Cent. Agr. Publ. Doc., Wageningen, The Netherlands.

Crasta, O.R. and W.J. Cox. 1996. Temperature and soil water effects on maize growth, development, yield, and forage quality. Crop Sci. 36:341-348.

Deetz, D.A., H.G. Jung, and D.R. Buxton. 1996. Water-deficit effects on cell-wall composition and in vitro degradability of structural polysaccharides from alfalfa stems. Crop Sci. 36:383-388.

Frank, A.B. and J.D. Berdahl. 1999. Soil water use by diploid and tetraploid Russian wildrye. Crop Sci. 39:1101-1106.

Frank, A.B. and J.D. Berdahl. 2001. Gas exchange and water relations in diploid and tetraploid Russian wildrye. Crop Sci. 41:87-92.

Greene, L.W., J.P. Fontenot, and K.E. Webb, Jr. 1983. Site of magnesium and other macromineral absorption in steers fed 
high levels of potassium. J. Anim. Sci. 57:503-510.

Halim, R.A., D.R. Buxton, M.J. Hattendorf, and R.E. Carlson. 1989. Water-deficit effects on alfalfa at various growth stages. Agron. J. 81:765-770.

Halim, R.A., D.R. Buxton, M.J. Hattendorf, and R.E. Carlson. 1990. Crop water stress index and forage quality relationships in alfalfa. Agron. J. 82:906-909.

Hides, D.H. and T.A. Thomas. 1981. Variation in the magnesium content of grasses and its improvement by selection. J. Sci. Food Agr. 32:990-991.

Jefferson, P.G., H.F. Mayland, K.H. Asay, and J.D. Berdahl. 2001. Variation in mineral concentration and grass tetany potential among Russian wildrye accessions. Crop Sci. 41:543-548.

Johnson. J.R. and J.T. Nichols. 1970. Plants of South Dakota grasslands-a photographic study. Bull. 566, Agr. Exp. Sta., South Dakota State Univ., Brookings, S. Dak.

Karn, J.F., L. Hofmann, and R.J. Lorenz. 1983. Russian wildrye nutritional adequacy and chemical composition. Agron. J. 75:242-246.

Kemp, A. 1960. Hypomagnesaemia in milking cows: the response of serum magnesium to alterations in herbage composition resulting from potash and nitrogen dressings on pasture. Neth. J. Agr. Sci. 8:281-304.
McDowell, L.R. 1997. Minerals for grazing ruminants in tropical regions. $3^{\text {rd }}$ Edition, Dept. of Anim. Sci. Bull., Center for Tropical Agr., Univ. of Fla., Gainesville, Fla.

Metson, A.J., W.M.H. Saunders, T.W. Collie, and V.W. Graham. 1966. Chemical composition of pastures in relation to grass tetany in beef breeding cows. N.Z.J. Agr. Res. 9:410-436.

Minson, D.J. 1990. Forage in ruminant nutrition. Academic Press. San Diego, Calif.

NRC. 1996. Nutrient requirements of domestic animals. Nutrient requirements of beef cattle. $7^{\text {th }}$ Edition. National Academy Press, Washington, D.C.

Perry, L.J., Jr. and D.D. Baltensperger. 1979. Leaf and stem yields and forage quality of three $\mathrm{N}$-fertilized warm-season grasses. Agron. J. 71:355-358.

Reeder, L.R., Jr., H.T. Nguyen, D.A. Sleper, and J. R. Brown. 1986. Genetic variability of mineral concentrations in tall fescue grown under controlled conditions. Crop Sci. 26:514-518.

Reynolds, J.H. and W.H. Wall, III. 1982. Concentrations of $\mathrm{Mg}, \mathrm{Ca}, \mathrm{P}, \mathrm{K}$, and crude protein in fertilized tall fescue. Agron J. 74: 950-954.

Ries, R.E. and L.G. Zachmeier. 1985. Automated rainout shelter for controlled water research. J. Range Manage. 38:353-357.
SAS. 1996. SAS System for mixed models. SAS Inst., Inc. Cary, N.C.

Sleper, D.A., K.P. Vogel, K.H. Asay, and H.F. Mayland. 1989. Using plant breeding and genetics to overcome the incidence of grass tetany. J. Anim. Sci. 67:3456-3462.

Underwood, E.J. 1977. Trace elements in human and animal nutrition. $4^{\text {th }}$ ed. Academic Press, New York, San Francisco, and London.

Vogel, K.P., B.C. Gabrielsen, J.K. Ward, B.E. Anderson, H.F. Mayland, and R.A. Masters. 1993. Forage quality, mineral constituents, and performance of beef yearlings grazing two crested wheatgrasses. Agron. J. 85:584-590.

Vough, L.R. and G.C. Marten. 1971. Influence of soil moisture and ambient temperature on yield and quality of alfalfa forage. Agron. J. 63:40-42.

Wilson, J.R. 1983. Effects of water stress on in vitro dry matter digestibility and chemical composition of herbage of tropical pasture species. Aust. J. Agr. Res. 34:377-390.

Wilson, J.R. and T.T. Ng. 1975. Influence of water stress on parameters associated with herbage quality of Panicum maximum var. trichoglume. Aust. J. Agr. Res. 26:127-136.

Wylie, M.J., J.P. Fontenot, and L.W. Greene. 1985. Absorption of magnesium and other macrominerals in sheep infused with potassium in different parts of the digestive tract. J. Anim. Sci. 61:1219-1229. 